\title{
Religiosity and mental suffering experiences of users of the Brazilian public healthcare system ${ }^{* 1}$ Religiosidade e experiências de sofrimento mental entre usuários da rede pública
} brasileira de saúde

\author{
Stephan Malta Oliveira*2 \\ Mônica Monteiro Peixoto*3 \\ Octavio Domont de Serpa Jr. ${ }^{* 4}$
}

This article aimed to investigate the relationship between religiosity and mental suffering experiences among users of the Brazilian public healthcare system, according to the cultural phenomenology framework. Its specific objective was to investigate the means by which the transformation of experience occurs. The study's design consisted of semi-structured interviews, applying the MINI - McGill Illness Narratives Interview. The results led to the construction of the following categories: causal factors, suffering experiences, healing practices, social support and positive transformation of the experience. The effects of religiosity on mental suffering experiences were predominantly positive, such as in religious rituals, social support and protection against suicide. The main healing mechanisms involved were embracement, symbolic and bodily processes, similarly to psychosocial approaches within professional ethnopsychiatries

Key words: Religiosity, mental suffering experience, cultural phenomenology, healing practices

*1 This article is the result of Stephan Malta Oliveira's postdoctoral research, conducted at the Institute of Psychiatry - UFRJ, under the supervision of prof. Octavio Domont de Serpa Jr., and collaboration of researcher Mônica Monteiro Peixoto.

*2, 3,4 Universidade Federal do Rio de Janeiro - UFRJ (Rio de Janeiro, RJ, Brasil). 
"If everything disappears, God is, and this is the only solid point"

(Karl Jaspers, 2018, p. 110)

\section{Introduction}

The present article results from a study that aimed to investigate and explore relationships between religiosity and the mental suffering experience (pathic experience) based on narratives of patients with mental illness assisted in the public mental health system of a mediumsized city located in the Southeast of Brazil. The specific objective consisted in investigating the means by which the transformation of experience occurs. Eight participants were intentionally selected, who had some kind of mental distress and attended a religion at least once a month. The study's design consisted of the conduction of semi-structured interviews with the administration of McGill Illness Narrative Interview (MINI), an instrument that aims to grasp in depth narratives about illness experiences.

According to Serpa Jr. et al. (2014), "the illness experience is related to the way in which the person who gets ill, their relatives and social network live, interpret, explain, deal with and respond to the suffering caused by an illness" (p. 1057). In our article, we will use the notions of mental illness, mental suffering and mental distress interchangeably.

The framework of this study is the field of cultural phenomenology, whose subject is the self embodied and situated in a social-culturalhistorical context (Csordas, 1997). In his works, like Body/Meaning/ Healing and The sacred self: a cultural phenomenology of charismatic healing, the north american anthropologist approaches the intrinsic relationship between the bodily and cultural dimension of the human being, overcoming dichotomies like subject-object, body-mind and nature-culture. Csordas (2008) shows that the field of perception, of sensitivity, is intertwined with the field of culturally shared symbols and meanings. He conceives the field of cultural phenomenology inspired 


\section{SAÚDE MENTAL}

by the phenomenology of Merleau-Ponty (1945/1999), according to which a person's body is constituted as the center of the lived experience, in its action in the world, pre-objective and anti-predicative, marked by historicity. Therefore, conscience is rooted in the body and situated in a context. MerleauPonty emphasizes interembodiment and Thomas Csordas (1997; 2008; 2015) has, as the center of his work, the paradigm of embodiment.

From this field, we will weave an interlocution with the related areas of phenomenology of the sacred and the North American medical anthropology, emphasizing the close relationship between body, culture, experience and narrative. The latter is understood as an integral and inseparable part of the lived experience.

The concept of experience is taken from phenomenology (Csordas, 1997) and from classical pragmatism (Dewey, 1929). This experience is both natural and cultural and emerges in the field of action of the human being in their environment (Dewey, 1929). Another aspect of the notion of experience adopted here is its pre-reflective dimension, related to what is immediately given, to what is implicit. Thus, the non-discursive dimension of experience neither founds nor determines linguistic meanings but, nevertheless, offers limits and possibilities to them (Dewey, 1929; Bezerra Jr., 2008). Therefore, the narrative, linked with implicit processes that accompany it, like actions, interactions and emotions, can only offer a partial picture of the totality of the lived experience, an unfinished view under constant construction (Rabelo, Alves \& Souza, 1999).

Since the emergence of medicine, narratives have been inseparable from medical practice and the act of "telling stories" is fundamental to diagnosis, prognosis and therapy (Leal et al., 2016; Greenhalgh \& Hurwitz, 1999). Greenhalgh and Hurwitz (1999) state that narratives confer meaning and perspective on the stories told by patients. In addition, narratives are performances, embodied acts that have potential for transforming experiences (Mattingly, 2004).

\section{Cultural and Bodily dimension of the religious experience}

One of the main concepts that guides the present article, originated from the field of medical anthropology, is the category ethnopsychiatries, formulated by Devereux (as cited in Gaines, 1992), which regards the study of mental suffering based on a transcultural perspective and refers to different 
forms of understanding, classifying and approaching mental affliction experiences. Gaines (1992) states that ethnopsychiatries can be professional - when practiced by health professionals - or folk, when practiced by healers, priests, pastors, shamans and other actors who do not belong to the field of health. There is an equal legitimation of folk and professional ethnomedicines and ethnopsychiatries. Kirmayer (2013) argues that the oldest approaches of transcultural psychiatry were part of colonial modes of thought, and their work was based on a universal system of knowledge grounded on positivistic science, seen as a-cultural. The post-colonial turn of the "new transcultural psychiatry", however, has shown that all knowledge systems, including the scientific one, have their social, cultural and historical roots, and culture and context are present in all aspects of experience.

Narratives that involve mental suffering, religiosity, and religious healing practices must be viewed taking into account the differences that characterize diverse socio-cultural contexts, especially the Western contexts, marked by secularization - in which there was a separation between religion and State, and the religious discourse and religious institutions lost their centrality in society in favor of technical-scientific discourses and practices - , and non-Western, non-secular contexts, in which religious institutions and the religious discourse continue to have an important place in societies. Gadit (2003) mentions the variety of modes in which mental distress is explained and understood in non-Western contexts, emphasizing the mystical and animistic understanding of mental suffering.

In the Brazilian context, there are important differences among social classes concerning the use they make of religious practices (relation between collective and individual; conceptions of causality and treatment of illnesses). It is important to mention that, because the study was conducted in the public mental health system of a Brazilian city, the majority of the participants belongs to the lower classes.

The Brazilian context is marked by a strong religious pluralism. The main religions in terms of number of members are Catholicism, with approximately $64.6 \%$, evangelical religions, with approximately $22 \%$, including the Pentecostal, Neo-Pentecostal and traditional religions (Methodist, Baptist, Presbyterian and Congregationalist), Spiritism, with approximately $2 \%$, and Afro-Brazilian religions like Candomblé and Umbanda, with approximately $0.3 \%$ (Brazilian Institute of Geography and Statistics [IBGE], 2010). The group "without religion" totals approximately $8 \%$ of the population, according to IBGE (2010). A qualitative analysis of the 


\section{SAÚDE MENTAL}

data, however, shows that many people who declare they are Catholics have other religious practices, not to mention the non-practitioners (Almeida \& Montero, 2001). Pentecostalism has been growing significantly in the lower classes. The majority of its members has not completed elementary education (65.2\%) (IBGE, 2010).

One of the main authors who contributed to a phenomenology of the sacred was Rudolf Otto, in his work The Idea of the Holy, published in 1917 (Otto, 1992). The central issue of this work revolves around the relationship between the rational and non-rational elements that are present in the religious experience. This dialectics between mystic-ecstatic elements and religious rationality, typical of the Enlightenment, was addressed by Max Weber (2010) in Sociology of Religion. Otto emphasizes the sphere of non-rational - the numinous, ${ }^{1}$ according to his words. According to Cruz (2009), the author aims to revisit this aspect of the studies of religion more specifically in the field of sciences of religion. This aspect has been neglected by the excessive rationalization of the Western secular culture. Otto (1992) criticizes the capture of the sacred dimension by means of conceptual and descriptive elements of God and faith only; at the same time, he values the feelings and emotions related to religiosity. On this sensitive dimension, some authors emphasize the intrinsic connection between the aesthetic and the sacred dimension (Stange \& Taylor, 2008). The dimension of the sacred is composed of a complex dialectics between rational and non-rational, and the latter is understood precisely as something that, due to "its deepness, escapes a rational explanation" (Otto, 1992, p. 86).

The issue of the religious experience, of the human being's relationship with the sacred, seen in the perspective of the ineffable, deserves a deeper discussion. In his article "O que diz o indizível" [What the unspeakable speaks], Pereira Jr. (2007) addresses the ineffable that is present in the religious dimension. The author distinguishes between the concept of God, which belongs to the realm of a collectivity and can be expressed and shared culturally, and the notion of unspeakable, which belongs to the category of the inaccessible, of what we cannot translate into words.

On the other hand, Pereira Jr. (2007) invites us to reflect on the possibility of a language about the ineffable, that is, about what cannot be

${ }^{1}$ Numinous is a neologism coined by Otto (1992) from the Latin term numen, which means “divine power". 
spoken. In this way, the meaning of unspeakable is opposed to itself, because if it is something we cannot speak, how can we represent it by a concept? How can we speak about an experience that exists "outside language" using language itself? Pereira Jr. (2007) addresses Wittgenstein's thesis about the impossibility of a private language (Wittgenstein, 1999).

This discussion about the ineffable seems to point to the relation that phenomenology establishes between the immediate experience, pre-reflective, and the reflective experience, mediated by language. We propose that one of the solutions for this impasse consists of thinking about the religious experience, when considered as belonging to the category of the "ineffable" - therefore, a particular type of religious experience that is closer to the ecstatic dimension - , not as an unspeakable or incommunicable experience, but as an experience characterized by a given affective intensity whose description and sharing is difficult, but not impossible. There will invariably be a certain imprecision and indetermination in the description of such experiences, but it will be possible to do it by resorting to more sophisticated linguistic resources, like metaphors. Indeed, the immediate experience can obviously be lived only by the person in question, which does not mean that it cannot be shared. However, there is a temporal gap between the instantaneity of affective experiences and the logic and linear sequence of language.

Within the field of phenomenology of religion, importance has been given to the body as the center of the religious experience. Ferrey (2010) carried out a study comparing different rituals in Christianity and Hinduism, emphasizing the bodily dimension of experience. According to the author, religious rituals like the Eucharist point to the centrality of the body in this type of experience, as it emerges as a tool used as a means of communion with the divine.

One of the forms of religious experience that has been a frequent object of study is the so-called embodied prayer (Snowber, 2004). One of the most famous is the Prayer of the Heart (Louchakova, 2004; Depraz, Varela \& Vermersch, 2003), which presents intrinsic connections with meditation practices. The Prayer of The Heart or Heart Prayer, is a part of Christian mysticism that was absorbed, later on, by the Orthodox Christian Church. This practice is also called Christian Yoga, due to its emphasis on bodily awareness (Louchakova, 2004). According to Depraz et al. (2003, p. 51), the prayer puts the person in the intimate presence of God, in a "quasi-sensible union" and, with practice, you develop a quality of "being intensely present to yourself", to your own body, to your "heart". 


\section{SAÚDE MENTAL}

Another religious practice that presents an interrelation between the Christian prayer and a meditation practice is described by Augustine Ichiro Okumura, a Japanese theologian raised in the interior of the Buddhist tradition who converted to Christianity. Okumura (1994) discusses the close relationship between the prayer and the person's intimacy, a perceptual awareness and silence.

At the extremity of prayer words vanish, or rather the "silence-becomeword" surpasses all that can be uttered. Prayer becomes the silence of Love, and this silence reveals the "I" in its deepest aspects; and should words suddenly arise in prayer, we must regard them as fruits of love that send us back to silence. (Okumura, 1994, p. 11)

\section{Methodology}

\section{Participants}

Eight participants were intentionally selected for the study. The majority of them was recruited through telephone calls made to patients assisted in psychiatric outpatient clinics of the public healthcare system of the chosen city. In the phone calls, the research coordinator asked the individuals enrolled in the outpatient assistance system if they attended religious services regularly and, if they did, with what frequency. Individuals who attended a specific religion less than once a month were excluded.

Overall, 38 calls were made. Some individuals did not answer the phone, 2 stated they were evangelical but refused to participate in the study, another 2 were non-practicing Catholics, and one evangelical individual agreed to participate, but missed the interview on the scheduled date. In the telephone recruitment, 6 individuals agreed to participate in the study. The rest did not meet the criteria for participation. A relevant fact is that one of the phone calls was answered by a person who is the mother of a patient who was already being assisted by the research coordinator. The coincidence surprised both sides and she agreed to participate. The other two participants were referred by two family doctors of the city. One of them referred two patients, one of whom attended the interview, and the other doctor referred one of the participants. In addition, one participant who had been referred by a member of a Spiritist center was excluded after the interview because it was verified 
that she did not attend the religious services; she just read Spiritist books and received help from the social program of the religious space.

Of the 8 subjects who participated in the study, 7 are women and 1 is a man; 5 are evangelical and 3 are Catholics. Although the majority of Brazilians are Catholics, a fact that may justify the higher number of evangelicals is that the study was carried out in the Brazilian public healthcare system; therefore, the majority of users belongs to the lower classes. Of the study's 8 subjects, 2 stated their monthly income ranges between 0 and 1000 reais (approximately 250 dollars according to a quote dated November $05,2019), 4$ between 1000 and 2000 reais (250 and 500 dollars), 1 between 2000 and 3000 reais (500 and 750 dollars), and 1 did not reveal the income. Their ages were 29, 35, 35, 36, 37, 47, 54 and 62 years. Regarding level of schooling, 2 completed elementary education, 1 did not complete secondary education, 1 completed secondary education, 1 did not complete higher education, 1 completed higher education, and 2 did not inform their level of schooling. Three subjects received treatment for mental suffering also in primary care and 5 only in secondary care. As for their origins, 1 subject was born in the State of Minas Gerais and the others in the State of Rio de Janeiro. Concerning churches, among the evangelical participants, 1 is from a protestant reformed church and the others are from Pentecostal or Neo-Pentecostal churches. As for the diagnosis, according to the medical records, the participants Claudia and Bernardo have anxiety disorder, Lourdes, Renata, Barbara and Beatriz have depressive disorder, Lucia has mixed anxiety-depressive disorder, and Marcela has bipolar disorder (the names are fictitious to preserve the anonymity of the information, according to the current ethical norms). The project was submitted to the Research Ethics Committee (CAAE 54045416.8.0000.5263) and approved under number 1.666.866. All the participants signed a consent document to participate in the study.

\section{Procedures}

The research project was written in 2015 and the bibliographic survey was carried out at the end of 2015 and in 2016. The participants were submitted to the McGill Illness Narrative Interview (MINI), an exploratory instrument that aims to collect in-depth narratives about illness experiences (Groleau, Young \& Kirmayer, 2006). This instrument was translated into Portuguese and validated by Leal et al. (2016). 


\section{SAÚDE MENTAL}

The McGill MINI is a semi-structured, qualitative interview that enables the production of narratives about illness experiences connected with any health problem, condition or event, including symptoms, set of symptoms, syndromes, biomedical diagnoses or popular labels, and the meanings associated with these experiences. (Leal et al., 2016, p. 5)

In addition, the MINI provides knowledge about cultural aspects shared by a group of individuals, as well as the way of constructing narratives and categories about health-related behaviors of cultural groups. The instrument is divided into five sections. The first one is related to narratives about the initial illness experience; the second is about prototype narratives and aims to identify, by analogy, previous illness experiences of the person him/ herself, similarities and differences in comparison to the current experience, and illness experiences of other people - relatives, friends or disseminated by the media; the third section focuses on explanatory model narratives and aims to identify the causes the person attributes to their health problem; the fourth section refers to services and response to treatment, like adherence to prescribed therapies, results, etc.; and the fifth and last section is related to the impact of the health problem on life: how the illness experience has changed the way the person looks at life, what has helped the individual through their health problem, if and how family, friends, faith and religious practice have helped, etc. (Leal et al., 2016). The dimension of religiosity received a greater emphasis during the interview, and some open questions about the theme were added to the Instrument. The interviews occurred between October 2016 and March 2017. Their duration ranged between 50 minutes and 1 hour and 20 minutes. The research subjects received transport and food allowances.

The interviews were transcribed during the year of 2017. Subsequently, between the end of 2017 and the second semester of 2018, the categorizations were constructed. The categories of analysis were constructed by two independent researchers - authors 1 and 2 of this article. At the end of 2018 and beginning of 2019, the categories were validated and selected by the 3 researchers who authored this article. The criteria for choosing the categories were their frequency and relevance to the research subject. The method used for data analysis was content analysis. 


\section{Results/Analysis of the Narratives}

The selected categories of analysis were: causal factors, suffering experiences, healing practices, social support and positive transformation of the experience.

\section{Causal Factors}

Causal factors regard the subjects' perception/understanding of the etiology of their health problem; therefore, it is attributed by the subjects themselves. The following subcategories were constructed within this category: biological, psychosocial and spiritual causal factors. "A job that I worked [...] there was a horrible pressure, I think there I got sicker" (Renata). In the fragment below, there is reference to the biomedical explanatory model of the "neurochemical imbalance", that is, a re-appropriation of medical knowledge by the participant. "Because depression, anxiety, is a chemical thing, too. So, sometimes, a chemical thing is missing and the medicine shall complement it and shall help you get better" (Lucia).

In the following fragment, there is a confluence of psychosocial and spiritual causal factors.

"I don't know, you become a womanizer, you end up drinking too much, losing... Prostituting yourself. I think that all these things lead a man to... end up taking the man away from that contact with God... that good thing of God and leave you exposed to the bad things of the world" (Bernardo).

Marcela talks about a moral rigidity in her church's religious belief and how this rigidity contributed to aggravate her health problem.

"I was facing a dilemma, because I wanted to divorce from my husband but the church does not allow it, God doesn't want it [...] I had to endure it and then I became sicker and sicker [...] because I am... an adulteress [...] and this title is for the rest of your life" (Marcela).

\section{Suffering Experiences}

This category encompasses reports of sadness, prostration, recurring intrusive thoughts, auditory hallucinations, and suicide attempts. "So that was how it began... I was very sick, I stayed in bed for three days, without showering, I didn't want to eat, to drink, to sleep..." (Claudia). 


\section{SAÚDE MENTAL}

In the fragment below, Bernardo reports his recurring thoughts of stabbing his girlfriend.

"I was stabbing her and she was hugging me, you know? And I was stabbing her and, suddenly, I realized I was looking at her with the knife in my hand and this made me so sad that I looked the other way, put the knife back there, left the kitchen and went to the living room" (Bernardo).

There are reports of self-injury, auditory hallucinations and suicide attempts. "As incredible as it may seem, it isn't painful. Cutting yourself isn't painful. It isn't painful at all. The pain we feel is greater than what you're doing" (Marcela). "It's like voices, something telling you: "there's no way, it's over, give up. Can't you see your life sucks?" (Marcela). "A blister pack of Losartan with a blister pack of I don't know what with a blister pack of my medicines and I'll take them and I'll die" (Lucia). In the following narrative, Marcela talks about how she behaved when she was in a euphoric mood. "Oh, I do a lot of things, a lot of things, I go out, I drink, I don't give a damn. (...) then, when I'm happy like this, sometimes I myself get scared" (Marcela).

\section{Healing Practices}

The suffering experiences lead to the search for help in different healing practices, both professional, within professional ethnopsychiatries, and religious, within folk ethnopsychiatries. Religious healing practices include both those practices performed during a religious celebration and broader religious-related processes such as the religious worldview.

Professional Healing Practices (subcategory)

Within the professional healing practices, there are reports of positive therapeutic effects regarding medicines and also embracement, conversation and attention on the part of therapists. "I started taking the medicine and things started to get better, I wanted to shower again, I wanted to take care of myself again" (Claudia). However, there are also many reports on the adverse effects of medicines. "Drops in blood pressure... I used to have a headache and I couldn't understand what that strange pain was, it came together with nausea, you know? And I stopped feeling it when I stopped taking the medicine" (Lucia) In this report, Lucia describes some of the side effects caused by the medicine lithium carbonate. 
In the report below, the participant criticizes the assistance provided by the psychologist. "When I said that I wanted to hurt people, I think she got scared and said: "Don't you want to be treated by someone else?" Then she threw me out to someone else." (Bernardo). In the fragment below, there is a praise to psychological assistance, to the importance of a healthy bond. "She talks to me. And everything I say it's like she knows everything I'm feeling. Whatever I say to her, she herself has already... Anything I tell her, she answers me immediately." (Marcela).

Religious Healing Practices (subcategory)

In relation to religious healing practices, there are several narratives about procedures and rituals performed in these practices (prayers, praises, spiritual counselling, Adoration of the Blessed Sacrament, speaking in tongues, Communion, anointing, retreats, offerings, cowrie-shells divination, etc.) that show that these rituals help people overcome suffering experiences. "Oh, my, I don't listen to music outside the... I just hear praises all the time, if I have to listen to music" (Renata). "It's the prayers you say that give you this support, because you're able to touch God's heart with your prayers. You open your heart to God (...) It's like intimacy" (Bernardo).

These reports show the importance of prayers, praises, and of the intimate contact with God. In the narrative below, Lourdes explains the relation between praying and healing according to her perception. An intrinsic relation can be noticed between the practiced ritual and the interpretation made by the participant, that is, the meaning attributed and shared by the church's members.

"I had a tumor in my liver... About 20, 25 years ago! Then, I went to church on a Thursday morning. God sent me a sister and she prayed for me there and I was healed. [...] everybody together there, the prayer circle (...) I felt like I was passing through [...] a machine that made me feel like that, right? You feel that illness like... as if God is cutting, healing, removing the illness, you know?" (Lourdes).

Lucia also portrays the importance of "speaking in tongues", more specifically, in the Charismatic Renewal Movement of the Catholic Church.

"It is a charismatic renewal movement. I participate in a prayer group [...] in the connection with the Holy Spirit, right, we sing, we cry out for the Holy Spirit, I don't know, we feel that presence, right, and the issue of praying in tongues, right?" (Lucia). 


\section{SAÚDE MENTAL}

Another participant talks about the importance of the spiritual counselling provided by her pastor.

"He prayed. First he prayed and after it, sometimes he read a verse from the Bible, right, he instructed you there in the Bible, he talked about what was happening, what I was feeling, he asked me and my husband. He advised and helped us" (Barbara).

Lucia, who calls herself a Catholic, describes one of her visits to the Candomblé and the ritual that was performed there, called Ebó. This trajectory of the participant points to the phenomenon of religious mobility, typical of the Brazilian religiosity, in which the faithful moves between one religion and the other (Dalgalarrondo, 2008).

"And then, she told me to change my clothes, she told me to put the old clothes on and said: 'Look, you'll keep your eyes closed, I'll turn you around during the procedure here, the process we'll perform here, right (yes), and you won't open your eyes. You can feel dizzy but I'll be holding you, you won't fall or anything'. Then I kept my eyes closed, they sang a song and she threw many things at me. I didn't see what they were but I could imagine, because there were many plates on the floor with things on them, there were little balls made of tapioca, there was popcorn, there were eggs... I felt the egg when she threw it at me, right, because it broke... (yes) Many things, they turned me round and round, they sang, she prayed Our Father, the Hail Mary, and they threw those things at me. Then, after this, I was allowed to open my eyes, it was dirty all around me, I only imagined how I was, right? There were no mirrors (Lucia).

The participant also tells about the work done for Iemanjá, ${ }^{2}$ where we can see in this and in the previous report the presence of a religious syncretism, that is, the presence of elements of another religion, in this case, Hail Mary and the Our Father of the Catholic Church. "Iemanjá 's offering is that she said she protected me, Iemanjá and São Jorge. Then I had to take some ribbons, flowers, they were more delicate things, perfume"(Lucia).

Other participant describe the so-called Adoration of the Blessed Sacrament in the Catholic Church and portray what they feel in relation to it, revealing the attribution of shared meaning related to the presence of the Holy Spirit.

${ }^{2}$ Female Orisha (African divinity) of the Afro-Brazilian religions. The name originates from the Yoruba language and means "Mother whose children are like fish". She is considered, in the worldview of these religions, the Goddess of the Sea and protector of fishermen. 
"It is the moment when we're in an intimate conversation with God, talking, speaking, praising [...] opening up to Him [...] There are moments of worship and moments of silence [...] The presence of the Holy Spirit, right? The Father, the Son and the Holy Spirit" (Beatriz).

The religious worldview and the support given by the religious Community - within the religious healing practices — are expressed in the following narratives. Religious worldview refers to the meanings shared by a religious community about lived experiences that help a person cope with his own suffering; the meanings are understood in this perspective as embodied acts, linked to actions.

The report below reveals God's presence in everything that happens in life, interceding for everyone. "The Bible says that not even a leaf falls off to the ground without God's permission" (Bernardo). Still about divine intercession, Beatriz talks about the day I called her to invite her to participate in the research. "Because I was already willing to speak, to get all these things off my chest. I said: 'Saint Rita, please help me'. Then I received your phone call' (Beatriz).

In the narrative below, the participant expresses a religious worldview associated with the Communion - a ritual performed in the Catholic Church. "And the Mass, we see it as if the Calvary were being revived, so, like, there's the Communion in the Mass, like, I truly believe that thing is the body of Christ, when consecrated by the priest" (Lucia).

Marcela describes, in one of her narratives, the compatibility and the conflict between religious view and medical knowledge, and that both can be present in the same church. "Yes, but there are teachings in church, of the older members, that say depression is an illness. That it needs to be treated" (Marcela). In another fragment: "well, they think it's a spirit, it's a spiritual problem, they don't understand" (Marcela).

Beatriz says that having faith in God can serve as protection against suicide. "If I didn't hang on to Him, I think I wouldn't be here anymore, I'd already have done something stupid [...] because sometimes desperation hits me and I really feel like I want to die." Some reports address the reason for living. The main sources are religiosity and the family. Renata portrays this aspect very well when she talks about what gives meaning to her life. "Well, my children, my grandchildren, my family and my search in God, as I still have hope in God" (Renata). However, in most of the reports about the meaning of life, religiosity appears as something that helps people to stay alive, not as a full sense. "I see that ... If it is not God, if it is not Him on 


\section{SAÚDE MENTAL}

the road ..., in my life, like this ... His love ... It has no purpose, it has no meaning! [...] Live for live, even more in the world we are living in [...] If you don't love God, you ... You better kill yourself and end it all "(laughs) (Bárbara).

Social Support

The social support category also emerges as an aspect of experience that helps the person to deal with their suffering, enabling its transformation. The subcategories are family, friends and religious community. Claudia talks about the support given by her ex-husband. "My daughter's father was extremely important in everything [...] he helped me a lot! (Claudia).

In relation to support provided by the religious community: "Yes, he visited me at home. Many times [...] When I was in crisis, feeling very upset, crying my eyes out. [...] And he was always there to help, always with me, my pastor" (Barbara).

In a specific situation, one of the participants reports her church did not support her when she divorced from her husband. "Many of them turned away from me. Many don't even speak to me anymore" (Marcela).

\section{Positive Transformation of the Experience}

The last category is "positive transformation of the experience", related to professional and religious healing practices. The narratives below reveal many rituals of religious healing practices related to the transformation of the emotional experience, like prayers, praises and the practice of "speaking in tongues". "Three times a week, that is a prayer, you know, so I feel very well, doctor, wow, it's wonderful!" (Lourdes). "So, I feel fine, I feel... It seems that the soul gets clean... I become happier, I tidy the house up... I don't play it loudly because I don't like it so loud. Then I listen to the praises and this has helped me a lot" (Claudia).

"That desire. You feel very hot, you feel something, and suddenly you start manifesting, speaking in tongues you never imagined you would speak" [...] It's pure joy [...] I've never felt anything like it. Interviewer: Really? Do you think this is a gift from the Holy Spirit? [...] Participant: I do, that's why I believe in God" (Marcela). 
There are also reports related to transformation of experience in the practice of Communion, in the Catholic Church, and in practices of helping other people. "It's gratifying [...] So, I feel good being able to help people." (Bernardo). "I feel very good when I help other people" (Lourdes). About the Communion: "I get there, well, very disturbed [...] It calms me down. It gives me a sense of peace. Sometimes, I feel like crying. But it generates joy. Happiness. (pause) That's it" (Beatriz). "I believe it helps me heal" (Lucia). However, the practice of helping other people appeared less frequently among participants and appeared to be sporadic in their lives.

\section{Discussion}

Among the causal factors described by the research participants, there is a holistic view, which meets the study by Minayo (1988) on the etiological conception of the popular classes about the health-disease process, integrating natural, emotional, supernatural and ecological explanations.

The suffering experiences lead to a search for help, either professional or folk-religious. In research, the participants looked for both practices. This is due to the methodological approach used, with respect to the selection criteria. We cannot say, in this way, from the data, whether in the Brazilian context the demand for people with mental suffering is predominantly professional, religious or both .We know that in some non-Western contexts, folk-religious ethnopsychiatries are the first choice to the detriment of professional ethnopsychiatries, like in Pakistan, Indonesia, Bangladesh and Tanzania, among many other societies (Gadit, 2003; Wilce Jr., 2004; Oliveira, 2014).

It was possible to notice the importance of both practices for the participants to overcome their suffering experiences and to transform them in a positive way. Among professional healing practices, the participants described many positive effects of medicines, as well as positive effects of hearing, embracement and "conversation", conducted mainly in psychological assistances. On the other hand, several side effects of the medicines were reported in almost all the interviews, and participants, although only a few, criticized psychology assistance.

Considering the relation between religiosity and mental suffering experience, a positive effect on suffering experiences was noticed in all the narratives. Among the positive effects, faith and religiosity emerge as a 


\section{SAÚDE MENTAL}

protection against suicide and a source of meaning for life. These findings are related to a positive religious coping (Koenig \& Larson, 2001; Lawrence, Orquendo \& Stanley, 2016). In addition to these, there were positive effects also related to religious rituals, social support and the practices of helping others.

Only one participant, Marcela, stated that religion had a negative effect on her emotional state, contributing to aggravate her suffering. These negative effects were mainly caused by lack of embracement on the part of the religious community, lack of support, and also due to value judgements related to a rigid religious belief, like in the specific case in which the participant was considered an "adulteress" because she separated from her husband. This finding corroborates studies showing that religions that have very rigid beliefs can contribute to aggravate fellings of guilt as well as depressive and anxiety symptoms (Koenig \& Larson, 2001; Dalgalarrondo, 2008). It works like a negative religious coping. Indeed, in the experience of the participant Marcela, despite the negative effect of her religious experience, there are reports of positive transformations of the experience, as in the ritual of speaking in tongues. At the end of the interview, she re-signifies her religious experience by saying that she no longer believes in a "punishing God" but in a "merciful God.": "I believe in God a lot, I love a lot, but I don't believe in this God I met anymore" (Marcela).

We cannot generalize, in general, that religiosity has more positive than negative effects on mental suffering experiences because it is a qualitative study with a small sample. But, we can say is that, in our study, most of the effects were positive. However, further qualifying the data, we can see that the main positive effects were related to the effects of religious rituals — transitory - of social support and related to protection against suicide. Narratives involving the practices of helping others and religiosity as a source of meaning for life were less recurrent. In some narratives, for example, the meaning for life appeared linked to the idea of staying alive. Even in participants who reported predominantly positive effects of religiosity, paradoxical narratives emerged, such as that of the participant Renata, related to the presence (see results) and the absence of meaning in life: "I arranged the children to go to school and I thought: " ah, why study, one day you will die, why study'? [...] So, I go on living to live" (Renata). An important point to note is that the psychopathological experience itself makes it difficult to access a sense of purpose in life. It is also worth mentioning that the practices of helping others and having a meaning in life are important indicators 
of mental health, in addition to being related to a more lasting positive transformation of the experience.

In all the conditions that emerged in the study and which result in a positive transformation of the experience, both symbolic and bodily processes play a part. The former includes therapeutic hearing, spiritual counselling and religious worldview, which corroborates the findings of Levi-Strauss (1958/2008) and Arthur Kleinman (1988a; 1988b) about symbolic efficacy and symbolic healing, respectively. The latter emerges in the various performances that take place at different religious spaces: in cults, in offerings and rituals in Afro-Brazilian religions, and in Masses, like in praises and prayers, which are accompanied by multiple forms of bodily expressions, ${ }^{3}$ such as raising arms, clapping and kneeling. These bodily procedures also emerge in the practices of "speaking in tongues", Adoration of the Blessed Sacrament and Communion, where there is a specific ritual to receive the body of Christ. These findings corroborate those described by Csordas (1997) and Rabelo (2008) about the importance of performance in religious healing rituals.

In the specific practice of praying, described by some participants as an "intimate encounter with God", there seems to be an intensification of

132 the sensitive and perceptual elements of the experience as described by studies about "the prayer of the heart" (Depraz, Varela \& Vermersch, 2003; Louchakova, 2004) and by Okumura's (1994) study about the importance of praying.

\section{Final Remarks}

The present research enabled us to draw some conclusions. Our data indicate a correlation between religiosity and suffering experiences. In our study, there was a positive association in the majority of narratives. The main positive effects were in relation to protection against suicide, social support and in relation to performative rituals in the various celebrations. The meaning for life and the practices of helping others were less recurrent. In an interview, the effect of religiosity on mental suffering experiences was predominantly negative.

\footnotetext{
${ }^{3}$ See “As técnicas do corpo" [Body techniques] in Marcel Mauss (2003).
} 


\section{SAÚDE MENTAL}

In relation to the mechanisms through which religious experiences and practices lead to healing, we found that the positive transformations of the experience mainly occur by means of embodied processes such as embracement, symbolic processes - and the contents of these processes, like the symbols and meanings of the sacred, in the context of our research, are extremely relevant — and bodily processes, like in performative rituals. Moreover, culturally shared practices and the sensitive dimension of experience - through rituals healing, love, embracement, help to other, silence, intuitions, sensations, feelings, etc. — seem to lead to healing and the sacred

We consider that folk ethnopsychiatries, like religious healing practices, are as important as professional ethnopsychiatries. Both of them are inserted in the same context of socio-cultural values and each one has its relevance according to specific purposes. Furthermore, religious practices cannot be reduced to therapeutic practices. They are, in fact, soteriological/salvation practices, essential to human existence, that can alleviate distress, help protect against suicide, enable positive transformations of experience, and give meaning to life.

We also consider that the mechanisms present in positive transformations of the experience obtained with religious practices are similar to the mechanisms present in psychosocial approaches within professional ethnopsychiatries as well as in traditional non-Western rituals. There seems to be a nonspecificity of action on various effective approaches in the mental health field, where symbolic and bodily processes operate. There are certainly similarities and some specificities regarding religious practices and psychosocial approaches. In both, embracement, and different narratives act as healing device. On the other hand, there are marked differences regarding the procedures and techniques used as well as regarding the content of the discourses. In addition, there is a significant difference regarding the purpose of both. Professional approaches seek healing while religious practices seek salvation. Although many faithful seek religion with an attempt to cure their ills, its primary purpose is salvation; and often, as an unintended effect, the heal is obtained.

This study has contributed to qualify the data from quantitative researches about religion and mental health. Further studies like the present one need to be carried out in an attempt to reach a better understanding of the mode of operation of processes that lead to healing in religious practices. 


\section{References}

Almeida, R., \& Montero, P. (2001). Trânsito religioso no Brasil. São Paulo em Perspectiva, 15(3), 92-101.

Bezerra Jr., B. (2008). A noção de experiência e sua importância para a clínica atual. In A. Arruda, B. Bezerra Jr., \& S. Tedesco (Orgs.), Pragmatismo, pragmáticas e produção de subjetividades (pp. 201-224). Rio de Janeiro, RJ: Garamond.

Cruz, J. R. B. (2009). Rudolf Otto e Edmund Husserl: considerações acerca das origens do método da Fenomenologia da Religião. Horizonte, 7(15), 122-141.

Csordas, T. (1997). The sacred self: A cultural phenomenology of charismatic healing. Berkeley and Los Angeles: University of California Press.

Csordas, T. (2008). Corpo/significado/cura. Porto Alegre, RS: Editora UFRGS.

Csordas, T. (2015). Cultural Phenomenology and Psychiatric Illness. In L. J. Kirmayer,. R. Lemelson \& C.A. Cummings (Eds.), Re-Visioning Psychiatry Cultural Phenomenology, Critical Neuroscience, and Global Mental Health (pp. 117-140). New York, NY: Cambridge University Press.

Dalgalarrondo, P. (2008). Religião, psicopatologia \& saúde mental. Porto Alegre, RS: Artmed.

Depraz, N., Varela, F. J., \& Vermersch, P. (2003). On becoming aware. Amsterdam/ Philadelphia: John Benjamins Publishing Company.

Dewey, J. (1929). Experience and Nature. London, UK: George Allen \& Unwin.

Ferrey, J. (2010). Faith embodied: A comparative analysis of the body's connection to religion through ritual in the Hindu and Christian context (Doctoral dissertation), University of Birmingham, United Kingdom. Retrieved from: <https://etheses. bham.ac.uk/id/eprint/1075/1/ferrey_10_MPhil.pdf>.

Gadit, A. A. (2003). Ethnopsychiatry: a review. Journal of Pakistan Medical Association, 53(10), 483-490.

Gaines, A. D. (1992). Ethnopsychiatry: The Cultural Construction of Psychiatries. In A. D. Gaines (Ed.), Ethnopsychiatry: The cultural construction of professional and folk psychiatries (pp. 3-49). Albamy, NY: State University of New York Press.

Greenhalgh, T., \& Hurwitz, B. (1999). Why study narrative? BMJ, 318, 48-50. doi: 10.1136/bmj.318.7175.48

Groleau, D., Young, A. Y., \& Kirmayer, L. J. (2006). The McGill Illness Narrative Interview (MINI): An Interview Schedule to Elicit Meanings and Modes of Reasoning Related to illness experience. Transcultural Psychiatry, 43(4), 697-717.

Instituto Brasileiro de Geografia e Estatística (2010). CENSO 2O1O. Retrieved from: https://censo2010.ibge.gov.br/ 


\section{SAÚDE MENTAL}

James, W. (1955). Pragmatism and four essays from the Meaning of Truth. New York, NY: Meridian Books, Inc. (Original work published in 1907).

Jaspers, K. (2018). A questão da culpa: a Alemanha e o Nazismo. São Paulo, SP: Todavia.

Kirmayer, L. (2013). 50 years of Transcultural Psychiatry. Transcultural Psychiatry, 50(1), 3-5.

Kleinman, A. (1988a). Rethinking Psychiatry: From cultural category to personal experience. New York, NY: The Free Press.

Kleinman, A. (1988b). The Illness Narratives: Suffering, Healing and the Human Condition. New York, NY: Basic Books Inc.

Koenig, H. G., \& Larson, D. B. (2001). Religion and mental health: evidence for an association. International Review of Psychiatry. 13, 67-78.

Lawrence, R. E., Orquendo, M. A., \& Stanley, B. (2016). Religion and Suicide Risk: A Systematic Review. Arch Suicide Res. 20(1), 1-21.

Leal, E. M., Souza, A. N., Serpa Jr, O. D., Oliveira, I. C., Dahl, C. M., Figueiredo, A. C., ... \& Groleau, D. (2016). McGill Entrevista Narrativa de Adoecimento-MINI: tradução e adaptação transcultural para o português. Ciência \& Saúde Coletiva, 21(8), 2393-2402

Levi-Strauss, C. (2008). Antropologia estrutural. São Paulo, SP: Cosac Naify. (First published 1958).

Louchakova, O. (2004). Essence of the Prayer of the Heart. In L. Lozowick, Gasping for air in a vacuum (pp. 35-50). Prescott, Arizona: Hohm Press.

Mattingly, C. (2004). Perfromance narratives in the clinical world. In B. Hurwitz, T. Greenhalgh, \& V. Skultans (Eds), Narrative Research in Health and Illness (pp. 73-94). Oxford, U.K.: Blackwell Publishing.

Mauss, M. (2003). As técnicas do corpo. In Mauss, M. Sociologia e antropologia. (pp. 399-422). São Paulo, SP: Cosac \& Naify.

Merleau-Ponty, M. (1999). Fenomenologia da percepção (2nd ed). São Paulo, SP: Martins Fontes. (first published 1945).

Minayo, M.C.S. (1988). Saúde-doença: uma concepção popular da etiologia. Cadernos de Saúde Pública, 4(4), 363-381

Okumura, A. I. (1994). Awakening to Prayer. (Translated by Theresa Kasue Hiraki \& Albert Masaru Yamato). Washington DC: ICS Publications Institute of Carmelite Studies.

Oliveira, S. M. (2014). Uma perspectiva multinível e plural em psiquiatria. (Doctoral dissertation), State University of Rio de Janeiro, Rio de Janeiro, Brasil.

Otto, R. (1992). O sagrado. Lisboa, PT: Ed. 70.

Pereira Jr., L.C. (2007). O que diz o indizível? Mirandum, XI(18), 49-55. 
Rabelo, M. C., Alves, P. C., \& Souza, I. A. (1999). Experiência de doença e narrativa. Rio de Janeiro, RJ: Editora Fiocruz.

Rabelo, M. C. (2008). Religião, ritual e cura. In P.C. Alves \& M.C.S. Minayo (Orgs.), Saúde e Doença: um olhar antropológico (pp. 47-56). Rio de Janeiro, RJ: Ed. Fiocruz.

Serpa Jr, O., Campos, R. O., Malajovich, N., Pitta, A. M., Diaz, A. G., Dahl, C, ... \& Leal, E. (2014). Experiência, narrativa e conhecimento: a perspectiva do psiquiatra e a do usuário. Physis Revista de Saúde Coletiva, 24(4), 1053-1077.

Snowber, C. (2004). Embodied Prayer: towards wholeness of body, mind, soul. Kelowna, BC, Canada: Wood Lake/Northstone.

Stange, K., \& Taylor, S. (2008). Relationship of personal cognitive schemas to the labeling of a profound emotional experience as religious-mystical or aesthetic. Empirical Studies of the Arts, 26(1), 37-49.

Weber, M. (2010). Sociologia das Religiões. São Paulo, SP: Ícone.

Wilce Jr., J. M. (2004). To "Speak Beautifully” in Bangladesh: Subjectivity as Pãgalãmi. In J. H. Jenkins, \& R. J. Barret (Eds.), Schizophrenia, culture and subjectivity - The Edge of Experience (pp. 196-218). New York, NY: Cambridge University Press.

Wittgenstein, L. (1999). Investigações Filosóficas. São Paulo, SP: Nova Cultural. (Original work published in 1953).

\section{Resumos}

(Religiosidade e experiências de sofrimento mental entre usuários da rede pública brasileira de saúde)

$O$ artigo teve como objetivo investigar a relação entre a religiosidade e as experiências de sofrimento mental entre usuários da rede pública de saúde brasileira segundo o referencial da fenomenologia cultural. Seu objetivo específico foi investigar os meios pelos quais a transformação da experiência ocorre. O desenho do estudo consistiu em entrevistas semi-estruturadas, aplicando-se o MINI - McGill Illness Narratives Interview. Os resultados levaram à construção das seguintes categorias: fatores causais, experiências de sofrimento, práticas de cura, suporte social e transformação positiva da experiência. Os efeitos da religiosidade sobre as experiências de sofrimento mental foram predominantemente positivos, como nos rituais religiosos, no apoio social e na proteção contra o suicídio. Os principais mecanismos de cura envolvidos foram o acolhimento, processos simbólicos e corporais, de modo similar às abordagens psicossociais dentro das etnopsiquiatrias profissionais

Palavras-chave: Religiosidade, experiência de sofrimento mental, fenomenologia cultural, práticas de cura 


\section{SAÚDE MENTAL}

(Religiosité et expériences de souffrance mentale chez les usagers système de santé publique brésilien)

Le but de cet article est d'étudier le rapport entre la religiosité et les expériences de souffrance mentale chez les utilisateurs du réseau de santé publique brésilien selon le cadre de la phénoménologie culturelle. Son objectif spécifique porte sur l'étude des moyens par lesquels la transformation de l'expérience a lieu. La conception de l'étude comprend des entrevues semi-structurées, appliquant l'entrevue McGill Illness Narratives Interview (MINI). Les résultats ont conduit à la construction des catégories suivantes: facteurs causaux, expériences de souffrance, pratiques de guérison, soutien social et transformation positive de l'expérience. Les effets de la religiosité sur les expériences de souffrance mentale étaient principalement positifs, comme dans les rituels religieux, le soutien social et la protection contre le suicide. Les principaux mécanismes de guérison impliqués étaient l'accueil et les processus symboliques et corporels, de la même manière que les approches psychosociales au sein des ethnopsychiatries professionnelles.

Mots clés: Religiosité, expérience de souffrance mentale, phénoménologie culturelle, pratiques de guérison

(Religiosidad y experiencias de sufrimiento mental entre los usuarios de la red pública de salud brasileña)

De acuerdo con el marco de la fenomenología cultural, el artículo tuvo como objetivo investigar la relación entre la religiosidad y las experiencias de sufrimiento mental entre los usuarios de la red pública de salud brasileña. Su propósito específico fue investigar los medios por los cuales se da la transformación de la experiencia. El diseño del estudio consistió en entrevistas semiestructuradas, aplicando la entrevista McGill Illness Narratives Interview (MINI). Los resultados llevaron a la construcción de las siguientes categorías: factores causales, experiencias de sufrimiento, prácticas curativas, apoyo social y transformación positiva de la experiencia. Los efectos de la religiosidad sobre las experiencias de sufrimiento mental fueron predominantemente positivos, como en los rituales religiosos, en el apoyo social y en la protección contra el suicidio. Los principales mecanismos de cura involucrados fueron el abrazo y los procesos simbólicos y corporales, de manera similar a los enfoques psicosociales dentro de las etnopsiquiatrías profesionales.

Palabras llave: Religiosidad, experiencia de sufrimiento mental, fenomenología cultural, prácticas curativas 
Citação/Citation: Oliveira, S. M., Peixoto, M. M., \& Serpa Jr., O. D. de (2021, março). Religiosity and mental suffering experiences among users of the Brazilian public healthcare system. Revista Latinoamericana de Psicopatologia Fundamental, 24(1), 115-139. http:// dx.doi.org/10.1590/1415-4714.2021v24n1p115-7.

Editoras/Editors: Profa. Dra. Erotildes Maria Leal

Submetido/Submitted: 2.2.2020/2.2.2020Ｒevisado/Revised: 20.5.2020 / 5.20.2020

Aceito/Acepted: $23.7 .2020 / 7.23 .2020$

Copyright: (C) 2009 Associação Universitária de Pesquisa em Psicopatologia Fundamental/ University Association for Research in Fundamental Psychopathology. Este é um artigo de livre acesso, que permite uso irrestrito, distribuição e reprodução em qualquer meio, desde que o autor e a fonte sejam citados / This is an open-access article, which permits unrestricted use, distribution, and reproduction in any medium, provided the original authors and sources are credited.

Financiamento/Funding: Este trabalho não recebeu apoio / This work received no funding.

Conflito de interesses/Conflict of interest: Os autores declaram que não há conflito de interesses. / The authors declare that there is no conflict of interest.

\section{Stephan Malta Oliveira}

Doutor em Saúde Coletiva, Instituto de Medicina Social, Universidade do Estado do Rio de Janeiro - UERJ (Rio de Janeiro, RJ, Br); Pós-doutorado em Psiquiatria pelo Programa de Pós-Graduação em Psiquiatria e Saúde Mental do Instituto de Psiquiatria da Universidade Federal do Rio de Janeiro - UFRJ (Rio de Janeiro, RJ, Br); Professor Adjunto de Neuropsiquiatria Infantil na Universidade Federal Fluminense - UFF (Niteroi, $\mathrm{RJ}, \mathrm{Br}$ ).

Av. Venceslau Brás 71, fundos - Campus da Praia Vermelha - Botafogo

22290-140 Rio de Janeiro, RJ, Br

stephanmoliveira@gmail.com

https://orcid.org/0000-0002-9806-9844

\section{Mônica Monteiro Peixoto}

Doutora em Saúde Mental pelo Programa de Pós-Graduação em Psiquiatria e Saúde Mental, Instituto de Psiquiatria, Universidade Federal do Rio de Janeiro - UFRJ (Rio de Janeiro, RJ, Br); Mestre em Saúde Coletiva, Instituto de Medicina Social, Universidade do Estado do Rio de Janeiro - UERJ (Rio de Janeiro, RJ, Br)

Av. Venceslau Brás 71, fundos - Campus da Praia Vermelha - Botafogo

22290-14 Rio de Janeiro, RJ, Br

monicamppsic@gmail.com

https://orcid.org/0000-0002-6832-8294 


\section{SAÚDE MENTAL}

Octavio Domont de Serpa JR.

Doutor em Psiquiatria e Saúde Mental pela Universidade Federal do Rio de Janeiro UFRJ (Rio de Janeiro, RJ, Br); Professor Associado do Instituto de Psiquiatria da mesma Universidade.

Av. Venceslau Brás 71, fundos - Campus da Praia Vermelha - Botafogo

22290-140 Rio de Janeiro, RJ, Br

domserpa@gmail.com

https://orcid.org/0000-0001-6827-4057

This is an open-access article, which permits unrestricted use, distribution, and reproduction in any medium for non-commercial purposes provided the original authors and sources are credited. 